\title{
Hot gas desulphurisation with dolomite sorbent in coal gasification
}

\author{
Ramón Álvarez-Rodríguez*, Carmen Clemente-Jul \\ Mining School, Technical University of Madrid (UPM), C/Rios Rosas, 21, 28003 Madrid, Spain
}

\begin{abstract}
A B S T R A C T
Gasification technologies are among the most promising electrical power generation options both from an environmental and efficiency point of view, as they allow efficient, environmentally-friendly use of national coal, as well as other carbonaceous materials mixed with coal, including high sulphur by-products.

During gasification, sulphur is converted mainly into $\mathrm{H}_{2} \mathrm{~S}$ and secondly into $\mathrm{COS}$, and control of these has been researched using several $\mathrm{H}_{2} \mathrm{~S}$ adsorbents. The aim of this paper was advanced removal of these compounds.

Dolomite, which reacts with $\mathrm{H}_{2} \mathrm{~S}$ to yield calcium sulphide, was chosen from among several earth-alkaline compounds for research due to its properties and low cost in reducing the presence of $\mathrm{H}_{2} \mathrm{~S}$ in coal gasification.

Tests were carried out using dolomite from Granada, Spain, with this sorbent used without blending and with amounts of $100 \mathrm{~g}$ and $150 \mathrm{~g}$ in each test. The dolomite was sulphurized using a mixture of gases that simulates the gasification gas.

The influence of sulphurisation conditions such as gas velocity, bed length, grain size, gas temperature, and gas composition were investigated. The solid products obtained were characterised by X-ray diffraction and chemical analysis.

The behaviour of $\mathrm{COS}$ that normally accompanies $\mathrm{H}_{2} \mathrm{~S}$ in gasification gases was investigated and found to follow a breakthrough curve similar to $\mathrm{H}_{2} \mathrm{~S}$, with equilibrium existing between the COS destroyed due to reaction with hydrogen and by hydrolysis and the $\mathrm{COS}$ formed by reaction of $\mathrm{CO}_{2}$ with $\mathrm{H}_{2} \mathrm{~S}$. Hence, its content in outlet gases is a function of the composition of this gas, especially in terms of $\mathrm{CO}_{2}, \mathrm{H}_{2} \mathrm{~S}$ and $\mathrm{H}_{2} \mathrm{O}$.

The accelerating effect of sulphurised dolomite on the rate of the reverse water-shift reaction was demonstrated.
\end{abstract}

Keywords:

Gasification

Desulphurisation

Dolomite

Coal

\section{Introduction}

In the gasification of coal or blends with other alternative fuels, sulphur is mainly present in the gas as hydrogen sulphide. This sulphur compound must be removed prior to gas combustion to comply with legislation and especially to avoid damage to the turbines. In the chemical industry, the presence of $\mathrm{H}_{2} \mathrm{~S}$ leads to larger corrosion problems (pipes, compressors, etc.) and also problems with some catalysts. The scrubbing of sulphur from the gas stream has been widely studied using different agents, such as the amines used by Elcogas IGCC in Spain; however, this option requires a decrease in gas temperature that causes the inherent energy losses.

Some sorbents that allow $\mathrm{H}_{2} \mathrm{~S}$ to be removed at high temperatures have been previously investigated; these include diverse metal compounds

Sorbent regeneration without significant degradation during a certain number of cycles is extremely important. Several $\mathrm{Zn}$ compounds some $\mathrm{Mn}$ and $\mathrm{Cu}$ compounds and blends and some Fe compounds have also been studied. The main problem is the sufficient duration of cycles without degradation. One very cheap oxide, $\mathrm{CaO}$, that does not need to be reused has also been studied. The main sources are two abundant minerals, calcite and dolomite. The direct addition of this oxide or the calcite in the gasification bed for coal gasification or the gasification of other alternative fuels has been investigated not only to clean the gas, but to produce hydrogen and also the absorption of $\mathrm{H}_{2} \mathrm{~S}$ in the oxides to remove them from the gas

Calcium oxide is effective in adsorbing $\mathrm{H}_{2} \mathrm{~S}$ from the gasification gases according to the reaction:

$\mathrm{H}_{2} \mathrm{~S}+\mathrm{CaO} \leftrightarrow \mathrm{CaS}+\mathrm{H}_{2} \mathrm{O}_{(\mathrm{g})} \quad \Delta H^{0}=-59.2 \mathrm{~kJ} \mathrm{~mol}{ }^{-1}$

but many studies with calcite or dolomite have been carried out on small samples in a thermobalance or differential reactor with $1 \mathrm{mg}$ to $1 \mathrm{~g}$ In other cases, larger amounts of absorbent have been used but mixed with silica grains to form a homogeneous 
mixture of sorbent and silica to avoid improper random distribution of the gas flow and reduce errors in the longitudinal conversion of profiles as in articles _. with the aim of obtaining appropriate measures to develop mathematical models.

In the case of an industrial application it would be appropriate to apply the pure absorbent which is why this investigation was carried out in this way and the different behaviour investigated according to grain size and position in the absorbent column: at the top or at the bottom subjected to more mechanical pressure. Absorbent amounts of $100 \mathrm{~g}$ and $150 \mathrm{~g}$ that give bed lengths of 11.4 and $17 \mathrm{~cm}$, respectively, were also used.

The absorbent chosen was dolomite as it works well under calcining $(1123 \mathrm{~K}$ ) and non-calcining conditions (1173 K) according to previous studied by Adanez

$\mathrm{H}_{2} \mathrm{~S}$ in the gasification gases is known to be accompanied by a certain proportion of carbonyl sulphide (COS) that when burnt, yields $\mathrm{SO}_{2}$ according to the following reaction:

$\mathrm{COS}+3 / 2 \mathrm{O}_{2} \leftrightarrow \mathrm{CO}_{2}+\mathrm{SO}_{2} \quad \Delta H^{0}=-552 \mathrm{~kJ} \mathrm{~mol}^{-1}$

This reaction increases the $\mathrm{SO}_{2}$ content of gases and increases the corrosive effect in gas turbines, gas motors, pipes and general industrial equipment and also increases $\mathrm{SO}_{2}$ emissions. Therefore, it should be reduced. At Elcogas, for example, this is carried out by $\operatorname{COS}$ hydrolysis according to the following reaction

$\mathrm{COS}+\mathrm{H}_{2} \mathrm{O}_{(\mathrm{g})} \leftrightarrow \mathrm{H}_{2} \mathrm{~S}+\mathrm{CO}_{2} \quad \Delta H^{0}=-33.6 \mathrm{~kJ} \mathrm{~mol}^{-1}$

$\mathrm{H}_{2} \mathrm{~S}$ is later eliminated by amine extraction.

There are various studies on COS hydrolysis especially aimed at the development of new catalysts such as rare earth oxysulphides but that require operating at relatively low temperatures.

However, the ability to reduce COS at high temperatures using the same approach as $\mathrm{H}_{2} \mathrm{~S}$ on earth alkaline sorbents would be of interest. This possibility has already been studied by Heesink but limited to lower temperature (up to $700^{\circ} \mathrm{C}$ ) and with a very small amount of sorbent and that postulates the reaction:

$\mathrm{CaO}+\mathrm{COS} \leftrightarrow \mathrm{CaS}+\mathrm{CO}_{2} \quad \Delta H^{0}=-90 \mathrm{~kJ} \mathrm{~mol}{ }^{-1}$

Ishida also postulates the reactions:

$\mathrm{CO}_{2}+\mathrm{H}_{2} \mathrm{~S} \leftrightarrow \mathrm{COS}+\mathrm{H}_{2} \mathrm{O}_{(\mathrm{g})} \quad \Delta H^{0}=+33.6 \mathrm{~kJ} \mathrm{~mol}^{-1}$

$\mathrm{CO}_{2}+2 \mathrm{H}_{2} \mathrm{~S} \leftrightarrow \mathrm{CS}_{2}+2 \mathrm{H}_{2} \mathrm{O}_{(\mathrm{g})} \quad \Delta H^{0}=+68 \mathrm{~kJ} \mathrm{~mol}^{-1}$

The proportion of $\operatorname{COS}$ to be expected will also depend on the concentrations of $\mathrm{CO}_{2}, \mathrm{H}_{2} \mathrm{~S}$ and $\mathrm{H}_{2} \mathrm{O}$ (reaction (5) is the reverse of (3)).

To achieve a reduction in $\mathrm{H}_{2} \mathrm{~S}$ and COS levels at very low values, some authors use $\mathrm{Zn}$ composites as absorbents that carry out desulphurisation over two stages, one to reduce the high level of $\mathrm{H}_{2} \mathrm{~S}$ at a low value, followed by another stage that uses an especially prepared absorbent with a high specific surface area.

In the present study, $\mathrm{H}_{2} \mathrm{~S}$ was contaminated with a small amount of $\operatorname{COS}$ (about $1 \%$ of the $\mathrm{H}_{2} \mathrm{~S}$ content) with the aim of investigating any decreases or increases under the test conditions, now operating with relatively large amounts of $100 \mathrm{~g}$ or $150 \mathrm{~g}$ of material. The contamination is sufficiently low so as not to decisively influence the principal sulphidisation reaction with hydrogen sulphide (1).

Another important reaction to consider is the reverse watershift reaction, which influences the proportion of $\mathrm{H}_{2}$ in the outlet gases, an important aspect if hydrogen is to be produced:

$\mathrm{CO}_{2}+\mathrm{H}_{2} \leftrightarrow \mathrm{CO}+\mathrm{H}_{2} \mathrm{O} \quad \Delta H^{0}=+41.1 \mathrm{~kJ} \mathrm{~mol}^{-1}$

\section{Experimental}

All experiments were performed using a dolomite from the province of Granada, Spain, that presented an essentially theoreti- cal composition. The X-ray diffractrogram and analysis are shown in Fig. 1 and Table 1, respectively. The chemical analysis was performed by X-ray fluorescence for the aforementioned elements and by gravimetric methods for insoluble material and loss on ignition.

This dolomite can be completely decomposed at $850^{\circ} \mathrm{C}$ as shown in Fig. 2, which contains the thermogram for dolomite in a nitrogen atmosphere $\left(40 \mathrm{~cm}^{3} / \mathrm{min}\right)$ with a temperature increase of $10^{\circ} \mathrm{C} / \mathrm{min}$ up to $850^{\circ} \mathrm{C}$, followed by constant temperature. A Setaram-Labsys thermobalance was used to obtain the thermograms.

The tests were conducted with a Kanthal vertical tubular reactor with a length of $1.6 \mathrm{~m}$ and inner diameter of $27 \mathrm{~mm}$, which passes, in its central part, through a furnace with an inner length of $600 \mathrm{~mm}$. This equipment was practically identical to the one used by Adánez (see Fig. 3).

The desulphuring column, laid out as a fixed bed, was formed by using $100 \mathrm{~g}$ or $150 \mathrm{~g}$ of dolomite classified granulometrically at $0.4-0.5 \mathrm{~mm}, 0.71-1 \mathrm{~mm}$ and $2-2.5 \mathrm{~mm}$ to obtain the different behaviour according to grain size. The dolomite was left at the top of the desulphuring column to study this relative position or at the bottom of a column of $250 \mathrm{~g}$ of silica of $1.6-2 \mathrm{~mm}$ (yielding a bed length of $30 \mathrm{~cm}$ ) to study the behaviour of absorbent located toward the bottom of a desulphuring bed under more static pressure (Fig. 3).

The initial sulphidising gases were introduced through the upper part of the reactor in order to flow across the bed of material to be sulphidised. These gases then came out through the lower end and flow through a coolant to separate out the water before the gases are analysed in a Varian CP-4900 Micro-GC gas analyser equipped with a $10 \mathrm{~m}$ column of Porabond $\mathrm{Q}$ and a thermal conductivity detector that took a sample every 5.7-6 min. The gases are analysed for $\mathrm{H}_{2} \mathrm{~S}, \mathrm{COS}, \mathrm{SO}_{2}$ and $\mathrm{CO}_{2}$.

To carry out sulphidisation tests, the dolomite sample was initially heated at $850^{\circ} \mathrm{C}, 900^{\circ} \mathrm{C}$ or $950^{\circ} \mathrm{C}$ (temperature measured by a thermocouple in contact with the dolomite sample) in a nitrogen atmosphere of $10 \mathrm{l} / \mathrm{min}$, which caused it to decompose. The time necessary to detect a $\mathrm{CO}_{2}$ content of less of $100 \mathrm{ppm}$ was noted and then the temperature was stabilised with the gas mixture at the velocity to be used, except $\mathrm{H}_{2} \mathrm{~S}$ and $\mathrm{H}_{2}$ and balanced with $\mathrm{N}_{2}$. The furnace resistor temperature was adjusted, as appropriate, to stabilise the temperature at the desired value.

Sulphidisation was produced by injecting the $\mathrm{H}_{2} \mathrm{~S}$ and $\mathrm{H}_{2}$ mixture and reducing $\mathrm{N}_{2}$ by the same amount. Gases continued to be added at $12.5,10$ and $5 \mathrm{l} / \mathrm{min}\left(36.4,29.1\right.$ and $\left.14.5 \mathrm{~cm} \mathrm{~s}^{-1}\right)$, considered by several authors as a typical case of plug flow _. . All gases were monitored by specific mass flow controllers and steam was obtained by complete evaporation of constant water flow moni-

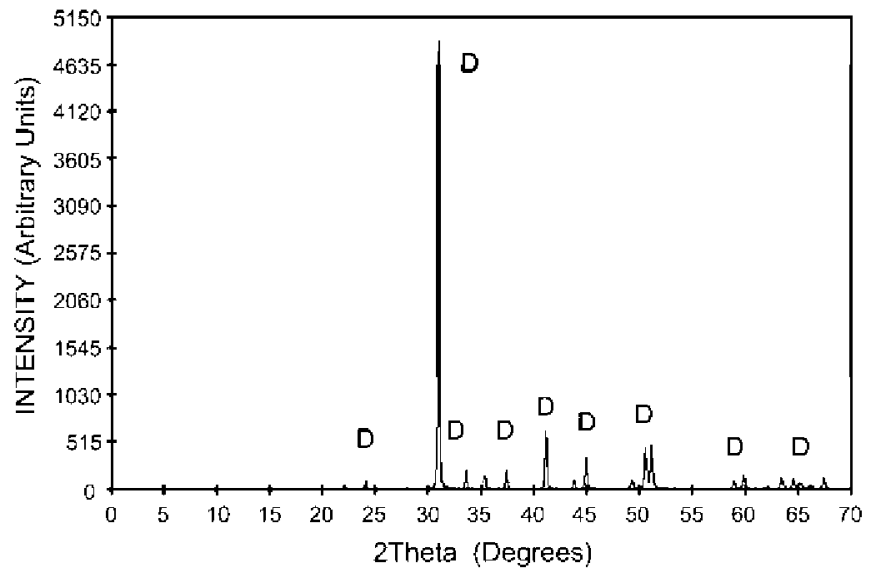

Fig. 1. Diffractogram of Granada dolomite used (D: dolomite). 
Table 1

Granada dolomite analysis

\begin{tabular}{lc}
\hline Element & Content\% \\
\hline $\mathrm{CaO}$ & 30.51 \\
$\mathrm{MgO}$ & 21.68 \\
$\mathrm{Fe}_{2} \mathrm{O}_{3}$ & 0.06 \\
$\mathrm{MnO}$ & 0.007 \\
$\mathrm{TiO}_{2}$ & 0.006 \\
$\mathrm{SiO}_{2}$ & 0.1 \\
$\mathrm{Al}_{2} \mathrm{O}_{3}$ & $<0.1$ \\
$\mathrm{~K}_{2} \mathrm{O}$ & $<0.1$ \\
$\mathrm{Na}_{2} \mathrm{O}$ & $<0.1$ \\
$\mathrm{P}_{2} \mathrm{O}_{5}$ & $<0.05$ \\
Insoluble & 0.20 \\
Loss on ignition & 47.53 \\
\hline
\end{tabular}

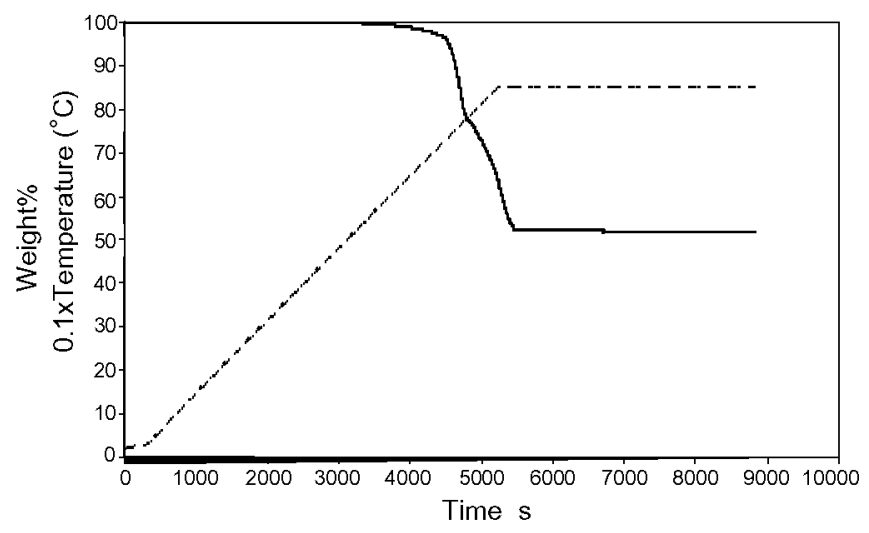

Fig. 2. Thermogram of the dolomite used (- weight, -- temperature).

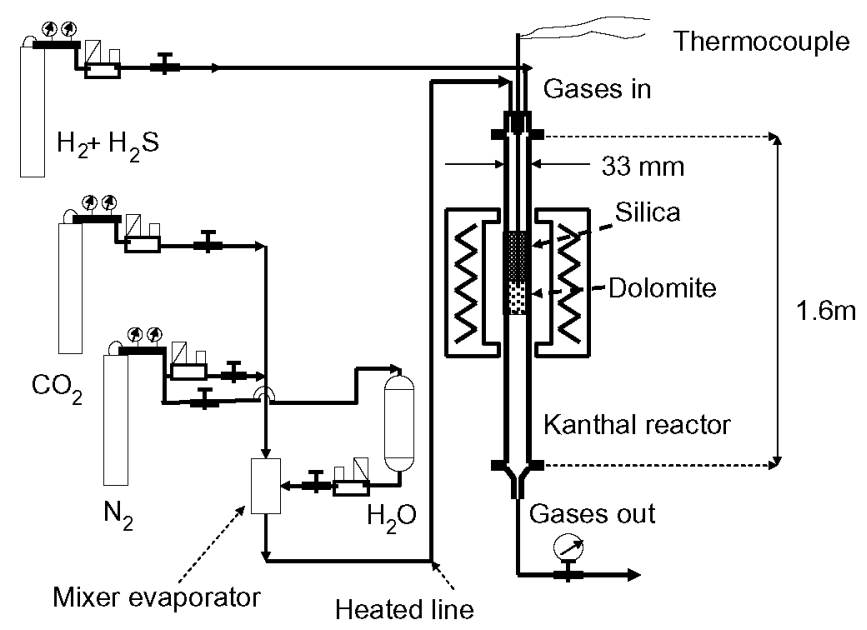

Fig. 3. Simplified chart of the system used. Dolomite at bottom position below a silica column.

tored by a mass flow controller and evaporator mixer. The certified deviations of the mass flow controllers (for flows measured under $75 \%$ of the fond scale) were lower than $\pm 0.3 \%$ of FS $( \pm 0.031 / \mathrm{min}$ for $\mathrm{N}_{2}$ and $0.0091 / \mathrm{min}$ for other gases).

Once the concentration of $\mathrm{H}_{2} \mathrm{~S}$ coming out was stabilised and approximately the same as the one being injected (except for changes in the minute amount of $\operatorname{COS}$ ), sulphidisation is completed. First, all gases were cut off except $\mathrm{N}_{2}$ and $\mathrm{H}_{2} \mathrm{~S}+\mathrm{H}_{2}$ and after a short time, $\mathrm{H}_{2} \mathrm{~S}$ was also cut off and then a $\mathrm{N}_{2}$ stream was passed to eliminate any gases that could impregnate the sample whilst the reactor was cooled by stopping the furnace current and opening the furnace.

The sulphidised sample was collected and analysed by X-ray diffraction and by chemical analysis when changing the sample size to control the degree of sulphidisation. All chemical analyses were done using gravimetric methods. A Phillips PX-1710 X-ray diffractometer was used.

Sulphidisation gases were formed from a mixture of gases: pure $\mathrm{N}_{2}$ as balance gas, pure $\mathrm{CO}_{2}$, pure steam, and a certified commercial mixture of $10 \% \mathrm{H}_{2} \mathrm{~S}$ and $90 \% \mathrm{H}_{2}\left(\mathrm{H}_{2} \mathrm{~S}\right.$ relative uncertainty of $\left.2 \%\right)$, that contains about $0.1 \% \operatorname{COS}$ monitored by gas chromatography according to certified standards, to obtain a sulphurisation gas with approximately $2 \% \mathrm{H}_{2} \mathrm{~S}$ to simulate gasification of sulphur-rich materials such as pet-coke, some coals, etc. and with another certified commercial mix of $2 \% \mathrm{H}_{2} \mathrm{~S}$ and $98 \% \mathrm{H}_{2}\left(\mathrm{H}_{2} \mathrm{~S}\right.$ relative uncertainty of $2 \%$ ) with approximately $0.02 \% \operatorname{COS}$ to obtain a gas for sulphurisation with $0.4 \%$ of $\mathrm{H}_{2} \mathrm{~S}$ and $19.6 \%$ of $\mathrm{H}_{2}$ to simulate the gasification of sulphur-poor substances.

The tests were carried out at atmospheric pressure with a slight excess pressure of approximately 0.1 bar to simulate the necessary pressure to circulate the gas; the pressure was $0.11 \mathrm{MPa}$.

Because hydrogen production is and will be important in the future and the shift reaction can be used for this and because gases to be desulphured do not have to be in equilibrium at the sulphidisation temperatures studied $\left(850-950^{\circ} \mathrm{C}\right)$, it was decided to study the behaviour of reaction (7) by not introducing $\mathrm{CO}$, but rather by forming $\mathrm{CO}$ via a reaction between the $\mathrm{CO}_{2}$ introduced and the hydrogen existing in the mixture. The action of the dolomite was then compared to the action of the silica (inert material).

The conditions used to test the dolomite are shown in Table 2 , along with other duplicate tests to confirm the results.

Tests were also carried out by replacing dolomite with silica, especially to study the behaviour of $\operatorname{COS}$ and the reverse watershift reaction (Table 2 ).

\section{Results and discussion}

\subsection{Absorption of hydrogen sulphide}

3.1.1. Influence of grain size, gas velocity and relative position in the desulphuring column (top or bottom)

By operating as described in Section 2, virtually complete (98$99 \%$ ) dolomite sulphidisation is obtained when the higher grain size of $2-2.5 \mathrm{~mm}$ was used, which would be the most difficult to sulphurise under different test conditions. Fig. 4 shows the X-ray diffraction of sulphurised dolomite, which contains no line of $\mathrm{CaSO}_{4}$ or $\mathrm{CaO}$, but rather only $\mathrm{CaS}$ (oldhamite) and $\mathrm{MgO}$ (periclase) lines.

Fig. 5 shows the breakthrough curves from various tests carried out at a gas velocity of 29.1 and $14.5 \mathrm{~cm} \mathrm{~s}^{-1}$ and considering the case of dolomite at the bottom of the desulphuring column under more static pressure (tests $2,3,7,9,10$ and 11 ; Table 2) and a test carried out with dolomite at the top of the column (test 6).

The $\mathrm{H}_{2} \mathrm{~S}$ concentration of the outlet gas has been plotted as a percentage with respect to the maximum output: $100 \%$ corresponds to approximately $20,000 \mathrm{ppm}$ of $\mathrm{H}_{2} \mathrm{~S}$, but not exactly as there are small variations due to a small variation in the proportions of outlet $\operatorname{COS}$ (see Section 3.2).

To explain the influence of the gas velocity, it was observed that the curves (for the three grain sizes) carried out at lower velocity are shifted toward the right but approximately retained their shape, a finding that is consistent with previous studies [19]. This occurs because a lower gas velocity was used, which meant that the amount of $\mathrm{H}_{2} \mathrm{~S}$ introduced per time unit was lower and that more time was needed to reach a definite degree of saturation. 
Table 2

Test Conditions for Calcined Dolomite Sulphurisation

\begin{tabular}{|c|c|c|c|c|c|c|c|c|c|c|c|}
\hline \multicolumn{7}{|c|}{ Test conditions } & \multicolumn{5}{|c|}{ Inlet gas ( $\mathrm{N}_{2}$ balance gas) } \\
\hline Test & Material & Grain size (mm) & Temp (K) & Bed length $(\mathrm{cm})$ & Gas velocity $\left(\mathrm{cm} \mathrm{s}^{-1}\right)$ & $\begin{array}{l}\text { Dolomite position } \\
\text { (top or bottom) }\end{array}$ & $\mathrm{H}_{2} \mathrm{~S} \%$ & $\cos (\mathrm{ppm})$ & $\mathrm{H}_{2} \%$ & $\mathrm{CO}_{2} \%$ & $\mathrm{H}_{2} \mathrm{O} \%$ \\
\hline 1 & Dolomite & $0.4-0.5$ & 1123 & 11.4 & 29.1 & $\mathrm{~T}$ & 2 & 176 & 18 & 6 & 10 \\
\hline 2 & Dolomite & $0.4-0.5$ & 1123 & 11.4 & 29.1 & B & 2 & 176 & 18 & 6 & 10 \\
\hline 3 & Dolomite & $0.4-0.5$ & 1123 & 11.4 & 14.5 & B & 2 & 176 & 18 & 6 & 10 \\
\hline 4 & Dolomite & $0.71-1$ & 1123 & 11.4 & 36.4 & $\mathrm{~T}$ & 2 & 176 & 18 & 6 & 10 \\
\hline 5 & Dolomite & $0.71-1$ & 1123 & 11.4 & 36.4 & $\mathrm{~T}$ & 2 & 176 & 18 & - & - \\
\hline 6 & Dolomite & $0.71-1$ & 1123 & 11.4 & 29.1 & $\mathrm{~T}$ & 2 & 176 & 18 & 6 & 10 \\
\hline 7 & Dolomite & $0.71-1$ & 1123 & 11.4 & 29.1 & B & 2 & 176 & 18 & - & - \\
\hline 8 & Dolomite & $0.71-1$ & 1123 & 17 & 29.1 & $\mathrm{~T}$ & 2 & 176 & 18 & - & 10 \\
\hline 9 & Dolomite & $0.71-1$ & 1123 & 11.4 & 14.5 & B & 2 & 176 & 18 & 6 & 10 \\
\hline 10 & Dolomite & $2-2.5$ & 1123 & 11.4 & 29.1 & B & 2 & 176 & 18 & 6 & 10 \\
\hline 11 & Dolomite & $2-2.5$ & 1123 & 11.4 & 14.5 & B & 2 & 176 & 18 & 6 & 10 \\
\hline 12 & Dolomite & $2-2.5$ & 1123 & 17 & 14.5 & B & 2 & 176 & 18 & 6 & 10 \\
\hline 13 & Dolomite & $2-2.5$ & 1173 & 11.4 & 14.5 & B & 2 & 176 & 18 & 6 & 10 \\
\hline 14 & Dolomite & $2-2.5$ & 1173 & 17 & 14.5 & B & 2 & 176 & 18 & 6 & 10 \\
\hline 15 & Dolomite & $2-2.5$ & 1223 & 11.4 & 14.5 & B & 2 & 176 & 18 & 6 & 10 \\
\hline 16 & Dolomite & $2-2.5$ & 1123 & 11.4 & 14.5 & B & 2 & 176 & 18 & 6 & - \\
\hline 17 & Dolomite & $2-2.5$ & 1123 & 11.4 & 29.1 & B & 0.4 & 38 & 19.6 & 6 & 10 \\
\hline 18 & Dolomite & $2-2.5$ & 1123 & 17 & 14.5 & B & 0.4 & 38 & 19.6 & 6 & 10 \\
\hline 19 & Sillica & $1.6-2$ & 1123 & 11.4 & 14.5 & B & 2 & 176 & 18 & - & - \\
\hline 20 & Silica & $1.6-2$ & 1123 & 11.4 & 14.5 & B & 2 & 176 & 18 & 6 & 10 \\
\hline 21 & Silica & $1.6-2$ & 1123 & 11.4 & 14.5 & B & 0.4 & 38 & 19.6 & - & - \\
\hline 22 & Sillica & $1.6-2$ & 1123 & 11.4 & 14.5 & B & 0.4 & 38 & 19.6 & 6 & 10 \\
\hline 23 & Silica & $1.6-2$ & 1123 & 11.4 & 14.5 & B & 0.4 & 38 & 19.6 & 6 & - \\
\hline
\end{tabular}

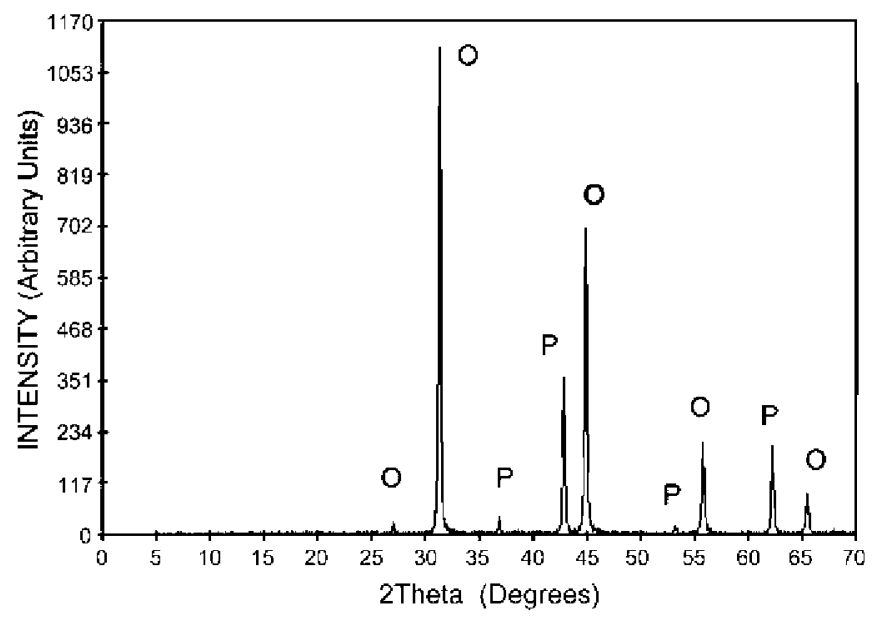

Fig. 4. Diffractogram of sulphurised Granada dolomite (O: oldhamite, P: periclase).

To explain the influence of grain size, it was observed that the curves corresponding to lower granulometries $(0.4-0.5 \mathrm{~mm})$ at the bottom have a flatter gradient than those corresponding to $2-2.5 \mathrm{~mm}$ at both gas velocities of 29.1 and $14.5 \mathrm{~cm} \mathrm{~s}^{-1}$. The tests with a grain size of 0.71 have an intermediate position. This shows that lower grain sizes results in greater grain packing in a compact bed of dolomite grains, thus creating preferential paths for the gas and delaying $\mathrm{H}_{2} \mathrm{~S}$ absorption. Therefore, under the conditions used, this means that a grain size of $2-2.5 \mathrm{~mm}$ will yield better results.

The effect of dolomite position can be observed by comparing the grain size of $0.71 \mathrm{~mm}$ with breakthrough curves at $29.1 \mathrm{~cm} \mathrm{~s}^{-1}$, one at the top and the other at the bottom. At the bottom position, the gradient is flatter.

The $0.71 \mathrm{~mm}$ curve at top position can also be compared with the curve of $2-2.5 \mathrm{~mm}$ at the bottom position, both at $29.1 \mathrm{~cm} \mathrm{~s}$ ${ }^{-1}$ : the curves are practically identical and have the shape of the breakthrough curves obtained by Adánez et al. (especially the curve for $0.71 \mathrm{~mm}$ ) who used silica mixtures to obtain more

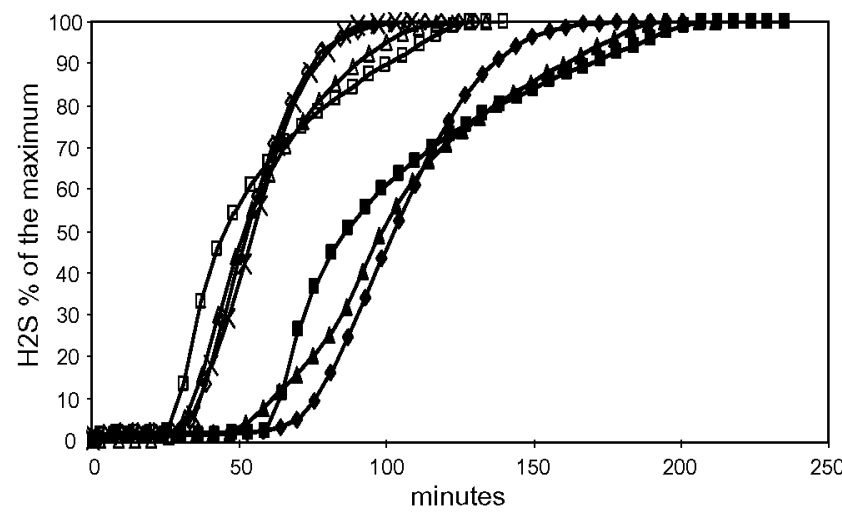

Fig. 5. Influence of grain size, gas velocity and relative position. Breakthrough curves for 11.4-cm bed length (Table 2 ): with dolomite at top position, test $6(x$, $0.71 \mathrm{~mm}, 29.1 \mathrm{~cm} \mathrm{~s}^{-1}$ gas velocity). With dolomite at bottom position and with $29.1 \mathrm{~cm} \mathrm{~s}^{-1}$ g.v., tests $2(\square, 0.4 \mathrm{~mm}), 7(\Delta, 0.71 \mathrm{~mm}), 10(\diamond, 2 \mathrm{~mm})$, and with $14.5 \mathrm{~cm} \mathrm{~s}^{-1}$ g.v., tests $3(\mathbf{\square}, 0.4 \mathrm{~mm}), 9(\Delta, 0.71 \mathrm{~mm})$ and $11(\diamond, 2 \mathrm{~mm})$

uniform permeability and to adjust the mathematical models. Under the conditions used, the curves at the bottom with the shape most closely resembling the mathematical models are those corresponding to a larger grain size $(2-2.5 \mathrm{~mm})$, in contrast with [19].

\subsubsection{Influence of temperature $\left(850^{\circ} \mathrm{C}, 900^{\circ} \mathrm{C}\right.$ or $\left.950^{\circ} \mathrm{C}\right)$}

Fig. 5 shows three curves for $100 \mathrm{~g}$ of sample $(11.4 \mathrm{~cm}$ bed thickness) and $2-2.5$ grain size, in bottom position sulphuring with $14.5 \mathrm{~cm} \mathrm{~s}^{-1}$ gas velocity, $2 \% \mathrm{H}_{2} \mathrm{~S}$ and temperatures of $1123 \mathrm{~K}$, $1173 \mathrm{~K}$ and $1223 \mathrm{~K}$ (test 11,13 , and 15 , Table 2 ).

Almost no differences in curve shape and values were observed between sulphidisation temperatures of $1123 \mathrm{~K}, 1173 \mathrm{~K}$ and $1223 \mathrm{~K}$, except for a difference in the smallest values (when a large part of the reagent had still has not reacted). This is consistent with other studies, but differs from the results obtained with calcite which showed a major variation in behaviour between $850^{\circ} \mathrm{C}$ and $900^{\circ} \mathrm{C}$. 


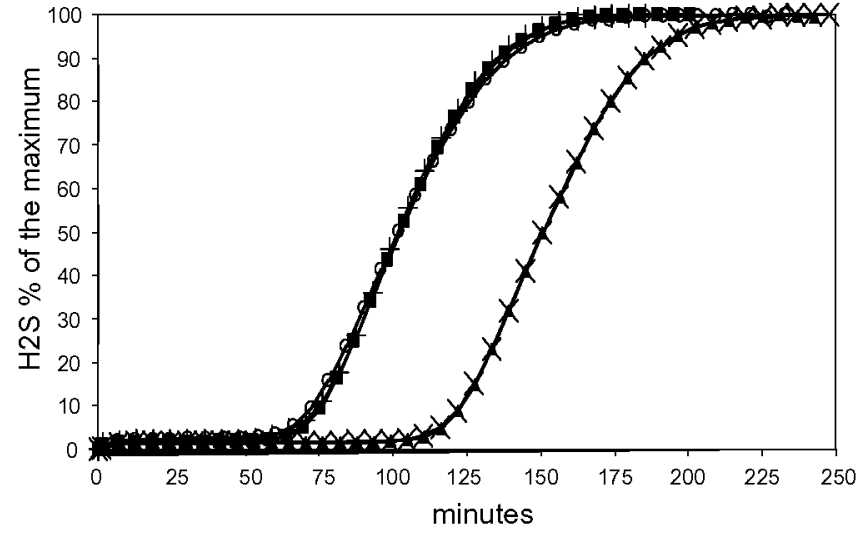

Fig. 6. Influence of temperature. Breakthrough curves at $850^{\circ} \mathrm{C}$ for tests (Table 2) $11(\mathrm{\square}, 11.4 \mathrm{~cm})$ and $12(\Delta, 17 \mathrm{~cm})$. At $900^{\circ} \mathrm{C}$, tests $13(+, 11.4 \mathrm{~cm})$ and $14(\times, 17 \mathrm{~cm})$. At $950^{\circ} \mathrm{C}$, test $15(0,11.4 \mathrm{~cm})$.

The curves are essentially identical for the three temperatures and show little influence of temperature in the case of dolomite in general. The initial area of the curves, where $\mathrm{H}_{2} \mathrm{~S}$ is more absorbed, is the most interesting part to consider in a possible reduction of the content in this substance in industrial gasification gases. Fig. 7 shows this extended area and reveals how the curves continue to be similar, but those for $850^{\circ} \mathrm{C}$ are a little below those for $900^{\circ} \mathrm{C}$ and $950^{\circ} \mathrm{C}$. Therefore, a temperature of $850^{\circ} \mathrm{C}$ should be used instead of $900^{\circ} \mathrm{C}$ or $950^{\circ} \mathrm{C}$ to minimise the amount of $\mathrm{H}_{2} \mathrm{~S}$ in the purified gas.

Figs. 6 and 7 also show two curves for $150 \mathrm{~g} \mathrm{(17} \mathrm{cm}$ bed thickness) in bottom-position sulphuring with $14.5 \mathrm{~cm} \mathrm{~s}^{-1}$ gas velocity, $2 \% \mathrm{H}_{2} \mathrm{~S}$ and temperatures of $1123 \mathrm{~K}$, and $1173 \mathrm{~K}$ (tests 12 and 14 , Table 2). Their behaviour under these results is similar to the previous curves.

The principal sulphurisation reaction is (1) and the value of its equilibrium constant for the case of calcining conditions can be expressed as

$K=P_{\mathrm{H}_{2} \mathrm{O}} / P_{\mathrm{H}_{2} \mathrm{~S}}=1.13 \exp (7262 / T)$.

At the beginning of sulphidisation, when practically all $\mathrm{H}_{2} \mathrm{~S}$ is adsorbed and taking in account the water generated by this adsorption reaction (1) and the water generated by the reverse shift reaction (7), the $\mathrm{H}_{2} \mathrm{~S}$ values in equilibrium at $1123 \mathrm{~K}, 1173 \mathrm{~K}$ and $1223 \mathrm{~K}$ are 208, 278 and $361 \mathrm{ppm}$, respectively (when $2 \% \mathrm{H}_{2} \mathrm{~S}$,

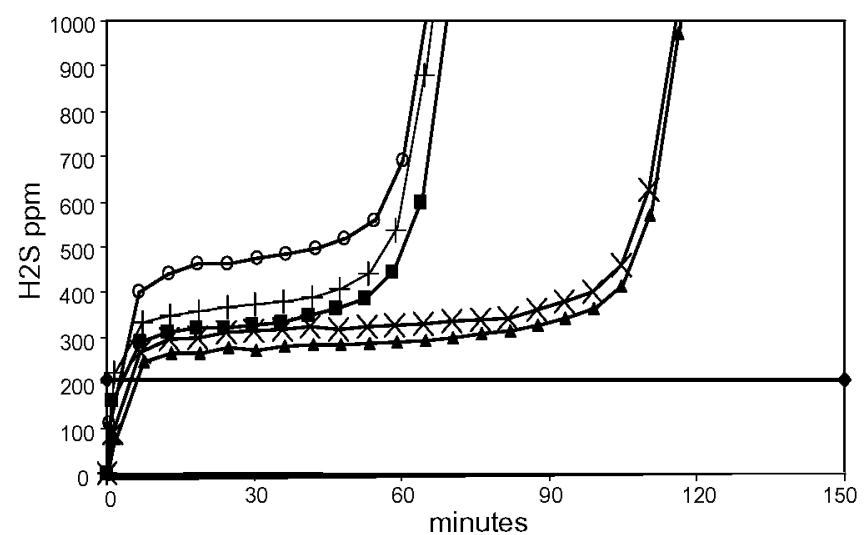

Fig. 7. Influence of temperature. Initial part of the breakthrough curves at $850^{\circ} \mathrm{C}$ for tests (Table 2) $11(\square, 11.4 \mathrm{~cm})$ and $12(\Delta, 17 \mathrm{~cm})$. At $900^{\circ} \mathrm{C}$, tests $13(+, 11.4 \mathrm{~cm})$ and $14(x, 17 \mathrm{~cm})$. At $950^{\circ} \mathrm{C}$, test $15\left(0,11.4 \mathrm{~cm}\right.$. Theoretical equilibrium $850^{\circ} \mathrm{C}$ : horizontal line $(\bullet)$
$18 \% \mathrm{H}_{2}, 6 \% \mathrm{CO}_{2}$ and $10 \% \mathrm{H}_{2} \mathrm{O}$ balanced with nitrogen are used). The higher the temperature, the higher the values of the $\mathrm{H}_{2} \mathrm{~S}$ concentration in equilibrium in accordance with the results presented.

These theoretical values are lower than the values observed for each set of parameters. Fig. 7 shows a plot of the theoretical value at $850^{\circ} \mathrm{C}$ which clearly indicates the difference.

\subsubsection{Influence of bed length}

Figs. 6 and 7 also show this influence in some tests with a grain size of only $2-2.5 \mathrm{~mm}$. In Fig. 6 the breakthrough curves of the test using $11.4 \mathrm{~cm}$ of bed length are grouped on the left side and those corresponding at $17 \mathrm{~cm}$ bed length are grouped on the right. There is a shift toward the right when bed length increases; this shift is independent of test temperature and occurs because a longer bed length means there is more solid to react and more time is needed to reach a particular conversion grade.

Fig. 7 contains a plot of the theoretical value of $\mathrm{H}_{2} \mathrm{~S}$ in equilibrium at $850^{\circ} \mathrm{C}$; this value is lower than the values observed at $850^{\circ} \mathrm{C}$ (tests 11 and 12 ). The difference is greater in the case of $11.4 \mathrm{~cm}$ compared with $17 \mathrm{~cm}$ because there is more solid to react and more contact time between the gas and solid when $17 \mathrm{~cm}$ is used instead of $11.4 \mathrm{~cm}$. This allows closer approximation to the theoretical value. Another conclusion is that even at the lower gas velocity used $\left(14.5 \mathrm{~cm} \mathrm{~s}^{-1}\right)$, a $17-\mathrm{cm}$ bed length is not enough to reach the theoretical value. Bed length is therefore an important parameter to narrow the gap between the potential results of a hypothetical industrial application and the theoretical values.

Fig. 8 also shows the influence of using a bed length of 11.4 or $17 \mathrm{~cm}$ under other conditions (tests 6, 8,12 and 13; Table 2). Tests 12 and $13\left(2.5-\mathrm{mm}\right.$ grain size, $\left.14.5 \mathrm{~cm} \mathrm{~s}^{-1}\right)$ have been discussed previously and test 6 and 8 have the same grain size $(0.71 \mathrm{~mm})$, gas velocity (29.1), position (top) and temperature $\left(850^{\circ} \mathrm{C}\right)$. In test $8(17 \mathrm{~cm})$, the curve is shifted toward the right hand when compared to test $6(11.4 \mathrm{~cm}$ bed length) and both curves have a similar gradient. Thus, this shift due to the bed length is produced with different grain sizes, gas velocities, sample positions in the desulphurising column, and temperatures.

Fig. 9 shows the initial part of the curves extended. The $\mathrm{H}_{2} \mathrm{~S}$ content of the outlet gases is lower with a longer bed length when compared with tests under other similar conditions, but with a shorter bed length.

\subsubsection{Influence of $\mathrm{H}_{2} \mathrm{~S}$ concentration in initial gases}

Fig. 10 shows an extension of the initial area of the breakthrough curves for several tests that jointly show tests performed

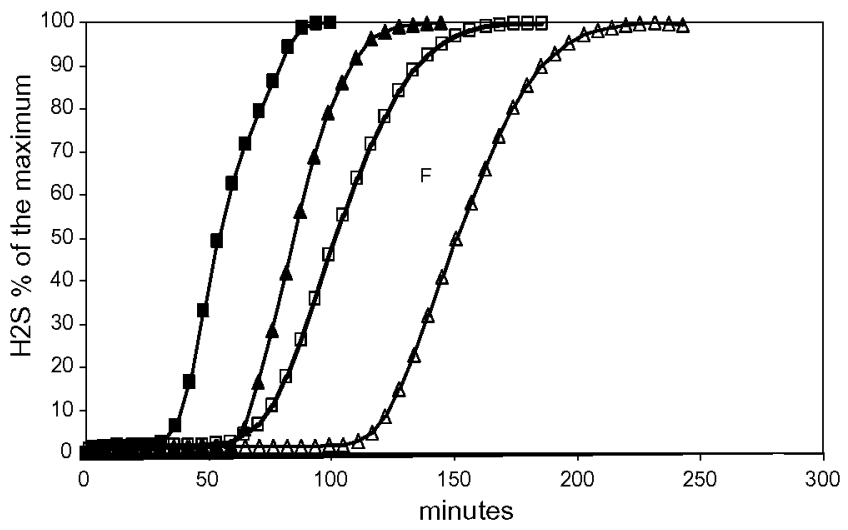

Fig. 8. Influence of bed length. Breakthrough curves for 11.4-cm: tests (Table 2) 6 (, $0.71 \mathrm{~mm}$, top position, $29.1 \mathrm{~cm} \mathrm{~s}^{-1}$ g.v.) and $13(\square, 2 \mathrm{~mm}$, bottom position, $14.5 \mathrm{~cm} \mathrm{~s}^{-1}$ g.v.). For $17-\mathrm{cm}$, tests $8\left(\Delta, 0.71 \mathrm{~mm}\right.$, top position, $29.1 \mathrm{~cm} \mathrm{~s}^{-1}$ g.v. $)$ and $12\left(\Delta, 2 \mathrm{~mm}\right.$, bottom position, $14.5 \mathrm{~cm} \mathrm{~s}^{-1}$ g.v.). 


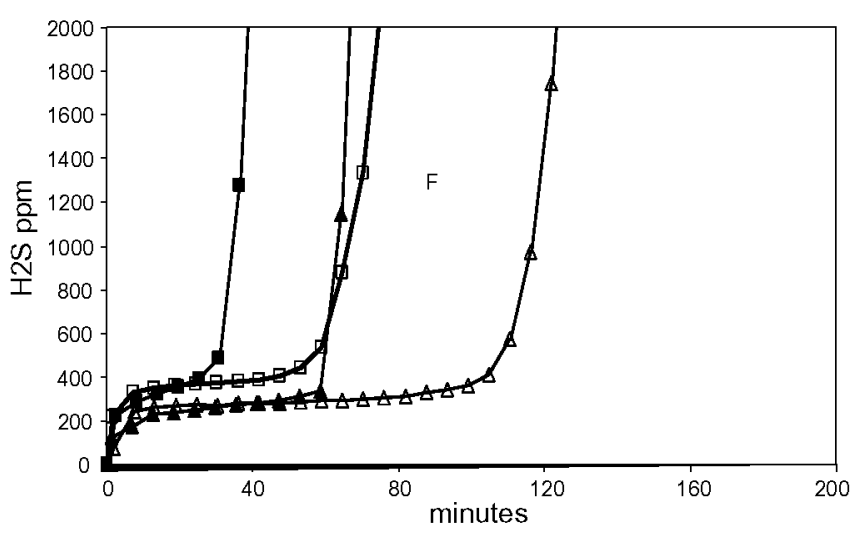

Fig. 9. Influence of bed length. Initial part of breakthrough curves for 11.4-cm: tests (Table 2) $6\left(\mathbf{\square}, 0.71 \mathrm{~mm}\right.$, top position, $29.1 \mathrm{~cm} \mathrm{~s}^{-1}$ g.v.) and $13(\square, 2 \mathrm{~mm}$, bottom position, $14.5 \mathrm{~cm} \mathrm{~s}^{-1}$ g.v. $)$. For $17-\mathrm{cm}$, tests $8\left(\Delta, 0.71 \mathrm{~mm}\right.$, top position, $29.1 \mathrm{~cm} \mathrm{~s}^{-1}$ g.v.) and $12\left(\Delta, 2 \mathrm{~mm}\right.$, bottom position, $14.5 \mathrm{~cm} \mathrm{~s}^{-1}$ g.v. $)$.

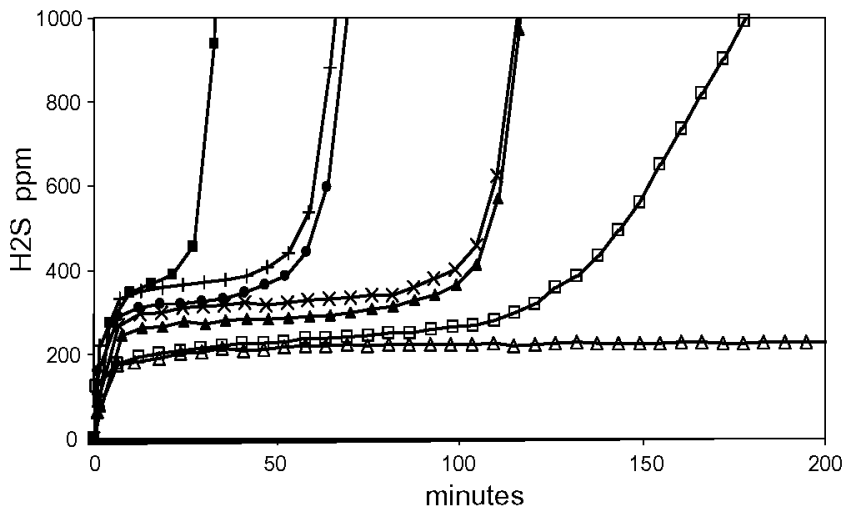

Fig. 10. Influence of $\mathrm{H}_{2} \mathrm{~S}$ concentration (2-2.5 $\mathrm{mm}$ grain size, bottom position). Initial part of breakthrough curves for $2 \% \mathrm{H}_{2} \mathrm{~S}$ concentration, tests (Table 2) 10 $\left(\square, 11.4 \mathrm{~cm}, 850^{\circ} \mathrm{C}, 29.1 \mathrm{~cm} \mathrm{~s}^{-1}\right.$ g.v. $), 11\left(\bullet, 11.4 \mathrm{~cm}, 850^{\circ} \mathrm{C}, 14.5 \mathrm{~cm} \mathrm{~s}^{-1}\right.$ g.v.), 12 (४, $17 \mathrm{~cm}, 850^{\circ} \mathrm{C}, 14.5 \mathrm{~cm} \mathrm{~s}^{-1}$ g.v.), $13\left(+, 11.4 \mathrm{~cm}^{\circ} 900^{\circ} \mathrm{C}, 14.5 \mathrm{~cm} \mathrm{~s}^{-1}\right.$ g.v.), 14 ( $\times$, $17 \mathrm{~cm}, 900^{\circ} \mathrm{C}, 14.5 \mathrm{~cm} \mathrm{~s}^{-1}$ g.v.), and for $0.4 \% \mathrm{H}_{2} \mathrm{~S}$ concentration, tests $17(\square$, $11.4 \mathrm{~cm}, 850^{\circ} \mathrm{C}, 29.1 \mathrm{~cm} \mathrm{~s}^{-1}$ g.v. $)$ and $18\left(\Delta, 17 \mathrm{~cm}, 850^{\circ} \mathrm{C}, 14.5 \mathrm{~cm} \mathrm{~s}^{-1}\right.$ g.v. $)$.

with $2 \% \mathrm{H}_{2} \mathrm{~S}$ (tests $10,11,12,13,14$ ) and tests with $0.4 \% \mathrm{H}_{2} \mathrm{~S}$ (tests 17 and 18). Test 17 has the same operating parameters as test 10 except for $\mathrm{H}_{2} \mathrm{~S}$ concentration and test 18 has the same operating parameters as test 12 except for $\mathrm{H}_{2} \mathrm{~S}$ concentration. Tests 17 and 18 performed with a concentration of $0.4 \% \mathrm{H}_{2} \mathrm{~S}$ have curves below the others. The decrease in the $\mathrm{H}_{2} \mathrm{~S}$ concentration of the inlet gases produces lower saturation at each point of the desulphurant column because there is less $\mathrm{H}_{2} \mathrm{~S}$ to react at any instant and relatively more free active points at any instant than at a higher $\mathrm{H}_{2} \mathrm{~S}$ concentration and therefore the reaction can produce results approaching the theoretical values.

The curves for tests 17 and 18 have a nearly flat initial stage that is practically identical; however, test 18 is slightly below test 17 due to longer bed length and lower velocity $(\Delta: 17 \mathrm{~cm}, 14.5 \mathrm{~cm} / \mathrm{s}$, instead of $\square: 11.4 \mathrm{~cm}, 29.1 \mathrm{~cm} \mathrm{~s}^{-1}$ ).

\subsubsection{Influence of composition of gas to be desulphured}

Given the principal sulphurisation reaction (1), the presence of steam will obviously be one of the factors controlling the balance of the reaction.

In gasification gases, the presence of steam is normally $10 \%$ or higher and the presence of $\mathrm{CO}_{2}$ may be around $3 \%$ in the case of entrained flow or higher in other cases. During sulphidisation, reac-

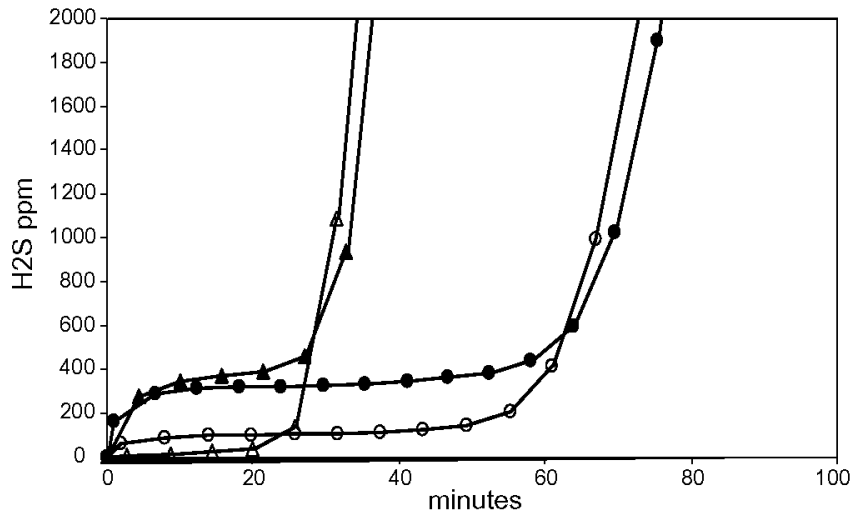

Fig. 11. Influence of gas composition $\left(11.4 \mathrm{~cm}, 850^{\circ} \mathrm{C}\right)$. Initial part of breakthrough curves with $\mathrm{CO}_{2}$ and $\mathrm{H}_{2} \mathrm{O}$, tests (Table 2) $10\left(\Delta, 29.1 \mathrm{~cm} \mathrm{~s}^{-1}\right.$ g.v.) and 11 ( $14.5 \mathrm{~cm} \mathrm{~s}^{-1}$ g.v.). With $\mathrm{CO}_{2}$ and without $\mathrm{H}_{2} \mathrm{O}$, test $16\left(0,14.5 \mathrm{~cm} \mathrm{~s}^{-1}\right.$ g.v.). Without $\mathrm{CO}_{2}$ and $\mathrm{H}_{2} \mathrm{O}$, test $7\left(\Delta, 29.1 \mathrm{~cm} \mathrm{~s}^{-1}\right.$ g.v. $)$.

tion (1) also yields water, especially in the initial stages in which nearly all $\mathrm{H}_{2} \mathrm{~S}$ reacts, which modifies the equilibrium.

When only nitrogen, hydrogen and $\mathrm{H}_{2} \mathrm{~S}(2 \%)$ are used (test 7, Fig. 11 ), only water generated in reaction (1) will be present (approximately $2 \%$ ). This is when the lowest $\mathrm{H}_{2} \mathrm{~S}$ values $(\Delta)$ are obtained in the outlet gases. Fig. 11 contains a comparison of tests $7,10,11$ and 16. When $6 \%$ of $\mathrm{CO}_{2}$ is introduced with no water (test 16 ) in such a way that the water present is that generated in reaction (1) plus that generated by reaction (7), there is more water (approximately $5.5 \%$ ) and higher results are obtained than in the previous case but lower than when $10 \%$ of water is introduced, test no. 10 and test no. 11 .

3.1.6. Conversion of calcium content in dolomite according to $\mathrm{H}_{2} \mathrm{~S}$ concentration in outlet gases and application to the case of $400 \mathrm{ppm}$ of $\mathrm{H}_{2} \mathrm{~S}$

Fig. 12 shows the curve of outlet $\mathrm{H}_{2} \mathrm{~S}$ normalised to $100 \%$ corresponding to test 12 . (Table 2) (150 g dolomite, $14.5 \mathrm{~cm} \mathrm{~s}^{-1}$ gas velocity, $850^{\circ} \mathrm{C}$ and grain size of $2-2.5 \mathrm{~mm}$ ).

According to chemical analyses at the end of the test, $\mathrm{CaO}$ conversion to CaS was about $99 \%$; therefore, the area over the curve in the plot represents the amount of $\mathrm{H}_{2} \mathrm{~S}$ used to convert practically all $\mathrm{CaO}$ into $\mathrm{CaS}(99 \%)$. This area can be calculated by integration of the amount adsorbed (20,000 ppm $-\mathrm{H}_{2} \mathrm{~S}$ content at each point) at each instant between 0 and the final time.

When integrating between 0 and each time point, the area represents the $\mathrm{H}_{2} \mathrm{~S}$ amount adsorbed up to that time. If this is ex-

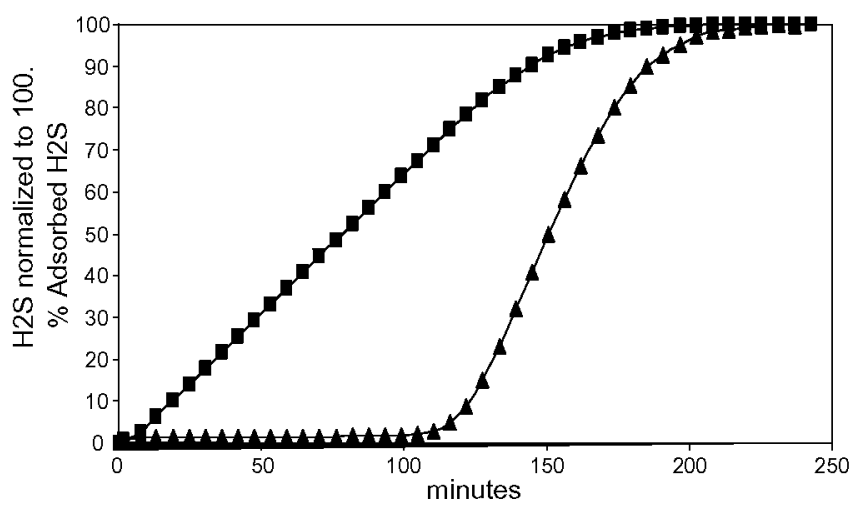

Fig. 12. Conversion to CaS during sulphurisation. $\mathrm{H}_{2} \mathrm{~S}$ breakthrough curve for test (Table 2) $12\left(\Delta, 850^{\circ} \mathrm{C}, 17 \mathrm{~cm}, 14.5 \mathrm{~cm} \mathrm{~s}^{-1}\right)$ and curve of\% CaS conversion ( $)$ 
pressed as a percentage of total area, then the percentage of $\mathrm{H}_{2} \mathrm{~S}$ absorbed with respect to the total is obtained; this is equivalent to a conversion percentage of disposable $\mathrm{CaO}$ at the time considered and at the respective outlet $\mathrm{H}_{2} \mathrm{~S}$ concentration. When integrating at all time points corresponding to the points of the curve, the curve that represents the percentage of $\mathrm{CaO}$ conversion is obtained ( $\boldsymbol{\square})$. As a result, this curve is also equivalent to the percentage conversion of $\mathrm{Ca}$ into CaS.

As observed initially, there is a practically linear growth that later tends towards a total of $100 \%$.

For any particular outlet $\mathrm{H}_{2} \mathrm{~S}$ concentration, the time can be determined from the $\mathrm{H}_{2} \mathrm{~S}$ breakthrough curve. This time allows the percentage of calcium conversion to be determined from the other curve.

Table 3 shows the Ca conversion for tests carried out with samples of $2-2.5 \mathrm{~mm}$ for a concentration of $400 \mathrm{ppm}$ of $\mathrm{H}_{2} \mathrm{~S}$ in the outlet gases.

Furthermore, under these conditions the concentration in the outlet gases is about $5 \mathrm{ppm}$ of COS (see Section 3.2).

Table 3 shows how the percentage of calcium converted increases as gas velocity decreases (test 11 as compared with test 10), bed length increases (test 12 as compared with test 11 , test 14 as compared with test 13 , and test 18 as compared with test 17), initial $\mathrm{H}_{2} \mathrm{~S}$ decreases (test 17 as compared with test 10 and test 18 as compared with test 12 ) and steam concentration in the initial gas decreases (test 16 as compared with test 11).

\subsection{Behaviour of $\operatorname{COS}$}

A total of $176 \mathrm{ppm}$ of $\operatorname{COS}$ was introduced with the mixture of $2 \% \mathrm{H}_{2} \mathrm{~S}$.

When a silica bed was used (test 19) in the same way as dolomite at $850{ }^{\circ} \mathrm{C}$ and the gas contains only $2 \% \mathrm{H}_{2} \mathrm{~S}, 18 \% \mathrm{H}_{2}$ and $176 \mathrm{ppm}$ of $\mathrm{COS}$ (balanced to $100 \%$ with $\mathrm{CO}_{2}$-free and steam-free $\mathrm{N}_{2}$ ) and the same conditions are used as in a dolomite sulphurisation test, then the COS value at the outlet drops to approximately $1.5 \mathrm{ppm}$ (already borderline for precision measurements using a gas chromatograph). Similarly, the $\mathrm{H}_{2} \mathrm{~S}$ content increases by approximately the same amount of COS, considering the relative errors to detect $176 \mathrm{ppm}$ in 20,000 . This shows that the following reaction is occurring:

$\mathrm{COS}+\mathrm{H}_{2} \leftrightarrow \mathrm{H}_{2} \mathrm{~S}+\mathrm{CO} \quad \Delta H^{0}:+7.4 \mathrm{~kJ} \mathrm{~mol}^{-1}$

A similar reaction occurs when dolomite is sulphurised with the mixture of $\mathrm{H}_{2} \mathrm{~S}, \mathrm{H}_{2}$ and $\mathrm{N}_{2}$ without adding $\mathrm{CO}_{2}$ or water (as in test 7 ). Fig. 13 contains the results $(\Delta)$ of this test, which shows even when the sample is totally sulphurised, the outlet COS concentration is also practically $1.5 \mathrm{ppm}$ (other curves under other conditions are shown in this figure).

Table 3

\% Calcium converted to CaS at $400 \mathrm{ppm} \mathrm{H}_{2} \mathrm{~S}$ in the outlet gas (2-2.5 mm grain size, bottom position)

\begin{tabular}{|c|c|c|c|c|c|c|c|c|}
\hline \multirow[t]{2}{*}{ Test } & \multirow{2}{*}{$\begin{array}{l}\text { Ca } \\
\text { converted } \\
\text { to CaS\% }\end{array}$} & \multicolumn{3}{|c|}{ Test conditions } & \multicolumn{4}{|c|}{ Inlet gas ( $\mathrm{N}_{2}$ balance gas) } \\
\hline & & $\begin{array}{l}\text { Bed } \\
\text { height } \\
(\mathrm{cm})\end{array}$ & $\begin{array}{l}\text { Gas } \\
\text { velocity } \\
\left(\mathrm{cm} \mathrm{s}^{-1}\right)\end{array}$ & $\begin{array}{l}\text { Temp } \\
(\mathrm{K})\end{array}$ & $\mathrm{H}_{2} \mathrm{~S} \%$ & $\mathrm{H}_{2} \%$ & $\mathrm{CO}_{2} \%$ & $\mathrm{H}_{2} \mathrm{O} \%$ \\
\hline 10 & 39 & 11.4 & 29.1 & 1123 & 2 & 18 & 6 & 10 \\
\hline 11 & 49 & 11.4 & 14.5 & 1123 & 2 & 18 & 6 & 10 \\
\hline 12 & 66 & 17 & 14.5 & 1123 & 2 & 18 & 6 & 10 \\
\hline 13 & 40 & 11.4 & 14.5 & 1173 & 2 & 18 & 6 & 10 \\
\hline 14 & 63 & 17 & 14.5 & 1173 & 2 & 18 & 6 & 10 \\
\hline 16 & 58 & 11.4 & 14.5 & 1123 & 2 & 18 & 6 & - \\
\hline 17 & 52 & 11.4 & 29.1 & 1123 & 0.4 & 19.6 & 6 & 10 \\
\hline 18 & 74 & 17 & 14.5 & 1123 & 0.4 & 19.6 & 6 & 10 \\
\hline
\end{tabular}

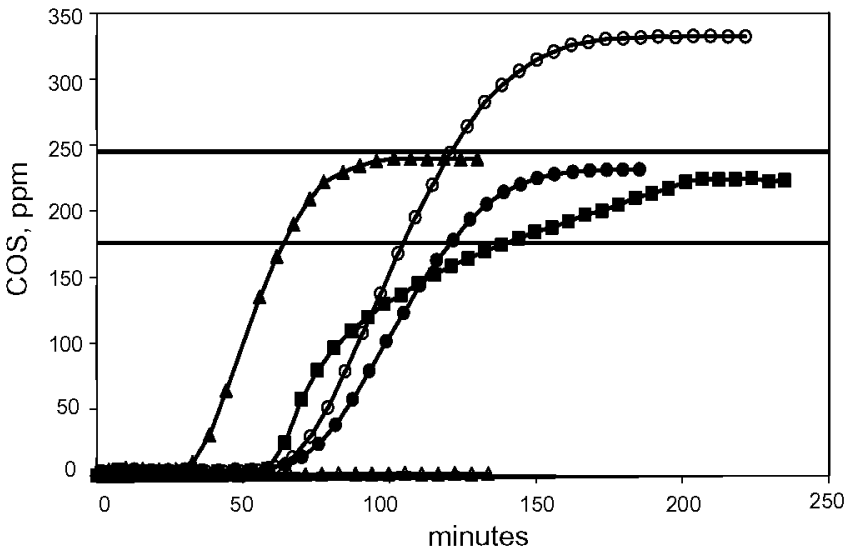

Fig. 13. COS in the outlet gas $(11.4 \mathrm{~cm})$. COS breakthrough curves with the usual inlet gas composition $\left(2 \% \mathrm{H}_{2} \mathrm{~S}, 6 \% \mathrm{CO}_{2}, 10 \% \mathrm{H}_{2} \mathrm{O}\right)$ for tests (Table 2$) 3(\boldsymbol{\square}), 10(\boldsymbol{\Lambda})$, and 13 ( and 20 (upper horizontal solid line) when silica is used instead dolomite. Without $\mathrm{CO}_{2}$, test $16(\mathrm{O})$. Without $\mathrm{CO}_{2}$ and $\mathrm{H}_{2} \mathrm{O}$, test $7(\Delta)$. Lower horizontal solid line: $\operatorname{Cos}$ introduced.

When silica is used (test 20, Table 2) and a mixture of $6 \% \mathrm{CO}_{2}$, $18 \% \mathrm{H}_{2}, 10 \% \mathrm{H}_{2} \mathrm{O}$ and $2 \% \mathrm{H}_{2} \mathrm{~S}$ (balanced to $100 \%$ with $\mathrm{N}_{2}$ ) at $850^{\circ} \mathrm{C}$ is passed, as used for most sulphurisation tests, the COS content of outlet gases becomes $245 \mathrm{ppm}$, in other words an increase in $\operatorname{CoS}$ content is observed and a similar decrease in $\mathrm{H}_{2} \mathrm{~S}$ content is detected. This fact can be explained by reaction (9) due to increasing CO content as a result of the reverse water-shift reaction (7).

When dolomite is used under the same gas composition conditions, Fig. 14 (tests 3,12 and 16), the $\operatorname{COS}$ and $\mathrm{H}_{2} \mathrm{~S}$ breakthrough curves have the same shape and are virtually identification, regardless of whether the curve is more or less "perfect". (To be able to compare both, the maximum amount produced by both composites is normalised to $100 \%$.) The same occurs with the curve obtained with another different composition of sulphurant gas without added water (test 16$)(\bullet$ and $\bigcirc$ ).

This suggests that $\mathrm{H}_{2} \mathrm{~S}$ and $\mathrm{COS}$ are linked by one o more chemical equilibria and that there may be competition between reactions (3), (5), and (9). However, given the direct relationship of curve shape and the $\mathrm{H}_{2} \mathrm{~S}$ content with $\mathrm{COS}$ in each specific case of each curve, it seems that reactions (5) and (9) are the two that basically control the appearance of $\mathrm{COS}$ the amount of $\mathrm{CO}_{2}$ and $\mathrm{H}_{2}$ present is much higher than the COS generated in all cases, except when neither $\mathrm{CO}_{2}$ nor $\mathrm{H}_{2} \mathrm{O}$ is used).

Under test conditions, the presence of $\mathrm{CS}_{2}$ has not been detected in the outlet gases and, therefore, reaction (6) does not

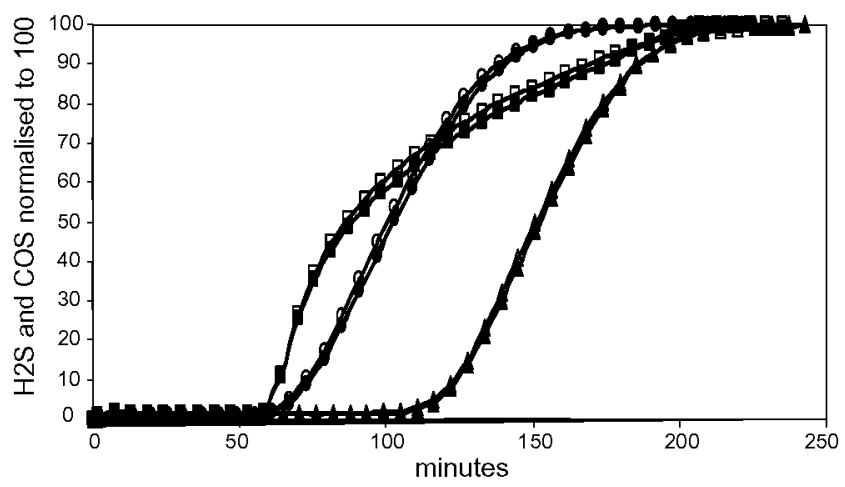

Fig. 14. $\mathrm{H}_{2} \mathrm{~S}$ and $\mathrm{COS}$ breakthrough curves under different operating conditions for tests (Table 2) $3(\boldsymbol{\square}, \square), 12(\Delta, \Delta)$ and $16(\bullet, 0) .\left(\mathrm{H}_{2} \mathrm{~S}: \mathbf{\square}, \bullet, \Delta\right.$, and Cos: $\left.\square, 0, \Delta\right)$ 
seem to take place in a detectable way. Under the gas chromatograph conditions used to analyse the outlet gases, the limit of graphical visual detection of the chromatographic pick of gases are about $1 \mathrm{ppm}$. As a result, another gas chromatograph detector, a differential mobility detector (DMD) specifically for sulphur compounds with a lower limit detection (under $0.1 \mathrm{ppm}$ ) was used; however, no signs of this compound were found.

Fig. 13 also shows the COS emission curves as absolute values of a series of tests carried out under different conditions (grain size, gas velocity) (tests 3,10 and 13 ) but with the same gas composition $\left(2 \% \mathrm{H}_{2} \mathrm{~S}, 18 \% \mathrm{H}_{2}, 6 \% \mathrm{CO}_{2}\right.$ and $\left.10 \% \mathrm{H}_{2} \mathrm{O}\right)$. Two lines have also been marked: one at $176 \mathrm{ppm}$ corresponding to the amount introduced in the case of tests with $2 \% \mathrm{H}_{2} \mathrm{~S}$ and another at $245 \mathrm{ppm}$ corresponding to the amount present when the same gas is passed through silica at $850^{\circ} \mathrm{C}$ (test 20 , Table 2 ), which corresponds to the conditions of most tests carried out.

The curve corresponding to test 10 carried out under the same conditions as with silica gives a maximum $\operatorname{COS}$ value ( $\boldsymbol{\Delta}$ ) only slightly below that corresponding to silica, which demonstrates similar behaviour when dolomite is saturated or completely sulphurised. The curve corresponding to test $13(\bullet)$, carried out at a slower gas velocity and higher temperature $\left(900^{\circ} \mathrm{C}\right)$ shows a similar trend, although its peak value is slightly below the previous case. This also occurs with the curve from test $3(\boldsymbol{\square})$. In all cases, the value is higher than the initial cos content. This demonstrates the low influence of grain size, gas velocity and temperature (in the range of $850-900^{\circ} \mathrm{C}$ tested) on maximum COS content if the gas composition is the same. This can be related to the equilibrium of chemical reaction (9) described above.

The influence of gas composition is evident in the curve from test $7(\Delta)$, carried out without added $\mathrm{CO}_{2}$ or $\mathrm{H}_{2} \mathrm{O}$. This curve has been discussed above and shows emissions of about $1.5 \mathrm{ppm}$ of COS. The behaviour is the same as for silica under the same conditions. This is easily explained by the equilibrium between $\mathrm{H}_{2} \mathrm{~S}$ and COS: if there is no $\mathrm{CO}$ except for the minimum amount produced by reaction (9), then this reaction is nearly completely shifted toward the right, causing the decomposition of $\operatorname{COS}$.

In contrast with the above paragraph, test 16 (Table 2) done without added steam shows that higher values of $\operatorname{COS}$ were obtained. The main difference from the test is the non-addition of water: only water generated in reactions (1) and (7) is present (approximately 5.5\%), leading to a higher level of $\mathrm{CO}$. The curve shape is identical to that of $\mathrm{H}_{2} \mathrm{~S}$ (Fig. 13); however, because there is a higher absolute value than with the most frequent gas composition used, hydrolysis reaction (3) is reduced due to the lower presence of $\mathrm{H}_{2} \mathrm{O}$ and the higher level of $\mathrm{CO}$ shifts reaction (9) toward the left contributing to this higher COS result.

\subsection{Influence on reverse water-shift reaction}

At the beginning of the sulphidisation process, when practically all $\mathrm{H}_{2} \mathrm{~S}$ reacts with $\mathrm{CaO}$ generated during dolomite calcination, an additional $2 \%$ of water is produced as in reaction (1) and this alters the equilibrium of reaction ( 7 ).

A variation in $\mathrm{CO}_{2}$ is observed from start to finish of the sulphidisation process, in which practically no water is produced and in which only water introduced in the gaseous mixture takes part. Fig. 15 (test 12) shows that, in comparison with silica, the reaction rate is highly accelerated; the $\mathrm{CO}_{2}$ level reached when dolomite is switched to silica is shown (solid line at the top of the plot).

The mean value calculated for the equilibrium constant of reaction (7) (eliminating the two initial points which are clearly outliers) is 1.14 , a figure consistent with the theoretical value of this constant at $850^{\circ} \mathrm{C}(1.144)$. The same occurs when operating at $900^{\circ} \mathrm{C}$ or $950^{\circ} \mathrm{C}$.

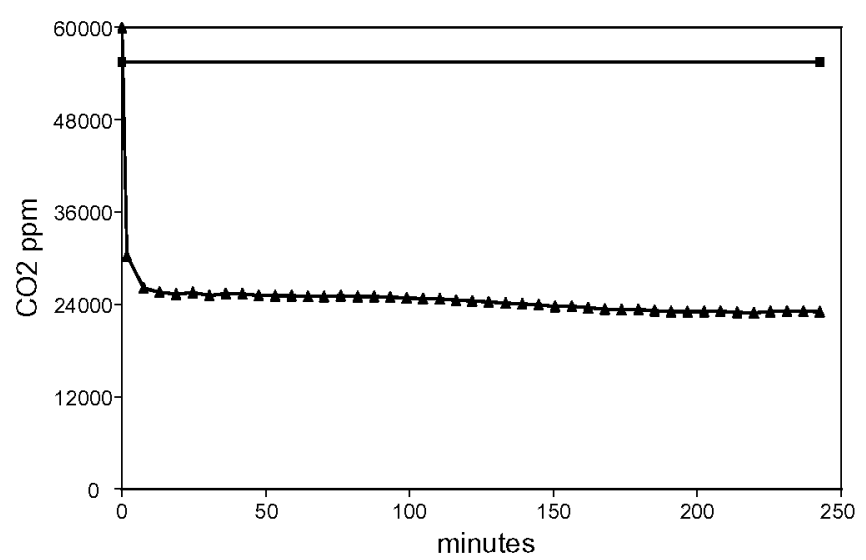

Fig. 15. Influence on reverse water-shift reaction. $\mathrm{CO}_{2}$ curve for test (Table 2 ) 12 ( $\left.850^{\circ} \mathrm{C}, 17 \mathrm{~cm}, 14.5 \mathrm{~cm} \mathrm{~s}^{-1}\right)$ and test $20(\boldsymbol{\square}$, same conditions with silica instead calcined dolomite)

\section{Conclusions}

(1) The principal factors for the decrease in $\mathrm{H}_{2} \mathrm{~S}$ content in the outlet gases of the desulphuration column in the initial stages of bed use are gas velocity, bed length and inlet $\mathrm{H}_{2} \mathrm{~S}$ concentration. Lower gas velocities, lower inlet $\mathrm{H}_{2} \mathrm{~S}$ concentrations and higher bed lengths result in lower $\mathrm{H}_{2} \mathrm{~S}$ content in outlet gases.

(2) Dolomite position at the top of the desulphurant bed or bottom (under more static pressure) is another important factor that conditions its use. The behaviour at the bottom is worse with smaller grain sizes.

(3) A temperature between $850^{\circ} \mathrm{C}$ and $950^{\circ} \mathrm{C}$ has very little influence on the overall characteristics of the breakthrough curves and only a slight influence on the initiation of the curves due to the influence of temperature on the equilibrium constant.

(4) Lower steam and $\mathrm{CO}_{2}$ concentrations in the inlet gas lead to significant reductions in the amount of $\mathrm{H}_{2} \mathrm{~S}$ present in the outlet gas in the initial adsorption stage of $\mathrm{H}_{2} \mathrm{~S}$.

(5) To reach an upper threshold (e.g., $400 \mathrm{ppm}$ ) of $\mathrm{H}_{2} \mathrm{~S}$ at the outlet, dolomite conversion with a bed length of $17 \mathrm{~cm}$ is approximately $68 \%$ with $2 \% \mathrm{H}_{2} \mathrm{~S}, 6 \% \mathrm{CO}_{2}, 18 \% \mathrm{H}_{2}$ and $10 \%$ steam at the inlet and approximately $2.6 \% \mathrm{CO}_{2}, 14.6 \% \mathrm{H}_{2}$ and $15.4 \%$ water at the outlet.

(6) Any $\operatorname{CoS}$ present shows the same trend as $\mathrm{H}_{2} \mathrm{~S}$ in its breakthrough curves.

(7) Temperature $\left(850^{\circ} \mathrm{C}\right.$ or $900^{\circ} \mathrm{C}$ ) has very little influence on the resulting $\operatorname{COS}$.

(8) The amount of COS present in the outlet gases is highly dependent on the composition of the gas, especially the content of $\mathrm{H}_{2} \mathrm{~S}, \mathrm{H}_{2}$, $\mathrm{CO}$ and steam.

(9) Sulphidised dolomite acts as a catalyst for the reverse watershift reaction, enhancing equilibrium at the temperature indicated. This should be considered when the intention is to produce hydrogen in the presence of $\mathrm{CO}_{2}$.

\section{Acknowledgements}

The authors would like to thank the European Commission - DG Research, Research Fund for Coal and Steel (RFC-CR-04006) for supporting this study.

The authors would also like to thank UPM-R05/11205(RFC M0500204145) and UPM-CCG06-UPM/TQ-351 (RFC M0700204178 ) for supporting this line of investigation of the research group. 


\section{Reference}

Westmoreland PR, Gibson JB, Harrison DP. Comparative kinetics of high temperature reaction between hydrogen sulphide and selected metal oxides. Environ Sci Technol 1997;11:488-91.

Christoforu SC, Efthiniadis EA, Vasolos I. Sulphidation of mixed metal oxides in a fluidized bed reactor. Ind Eng Chem Res 1995;34:83-93.

Tomás-Alonso F, Palacios JM. Synthesis and surface properties of zinc ferrite spices in supported sorbents for hot-coal gas desulfurization. Fuel Process Technol 2004:80:191-203.

Pineda M, Palacios JM, Alonso L, García E, Moliner R. Performance of Zn oxide based sorbents for hot-coal gas desulfurization. Fuel 2000;79:885-95.

Alonso L, Palacios JM, Moliner R. The performance of some $\mathrm{Zn}$ based regenerable sorbents in hot coal gas desulphurization long-term using graphite as a pore-modifier additive. Energy Fuels 2001;15:1396-402.

Ahmed MA, Alonso L, Palacios JM, Cilleruelo C, Abanades JC. Structural changes in $\mathrm{Zn}$ ferrites as regenerable sorbents for hot coal gas desulphurization. Solid State Ion 2000;138:51-62.

Alonso L, Palacios JM, García E, Moliner R. Characterization of $\mathrm{Mn}$ and Cu oxides as regenerable sorbents for hot coal gas desulphurization. Fuel Process Technol 2000;62:31-44.

García E, Palacios JM, Alonso L, Moliner R. Performance of Mn and Cu mixed oxides as regenerable sorbents for hot coal gas desulfurization. Energy Fuels 2000;14:1296-303.

Alonso L, Palacios JM. Performance and recovering of a $\mathrm{Zn}$-doped Mn oxide as a regenerable sorbent for hot-coal gas desulfurization. Energy Fuels 2002;16:1550-6.

Pan YG, Perales JF, Velo E, Puigjaner L. Kinetic behaviour of iron oxide sorbent in hot gas desulphurization. Fuel 2005;84:1105-9.

Risnes $\mathrm{H}$, Fjellerup J, Henriksen $\mathrm{H}$, Moilanen A, Norby P, Papadakis K, et al. Calcium addition in straw gasification. Fuel 2003;82:641-51.

Lin S, Harada M, Suzuki Y, Hatano $H$. Continuous experiment regarding hydrogen production by coal/CaO reaction with steam (I) gas products. Fuel 2004;83:869-74.
Adánez J, Diego LF, García-Labiano $\mathrm{F}$, Abad A. Kinetics of $\mathrm{H}_{2} \mathrm{~S}$ reaction with calcined calcium-based sorbents. Energy Fuels 1998;12:617-25.

García-Labiano F, Adánez J, Abad A, Diego LF, Gayan P. Effect of pressure on the sulfidation of calcined calcium based sorbents. Energy Fuels 2004;18:761-9. Adánez J, Abad A, Diego LF, García-Labiano F, Gayan P. Direct sulphidation of half-calcined dolomite under pressurized conditions. Ind Eng Chem Res 2004;43:4132-9.

Diego LF, García-Labiano $\mathrm{F}$, Adánez J, Palacios JM. Factors affecting the $\mathrm{H}_{2} \mathrm{~S}$ reaction with non-calcined limestones and half-calcined dolomite. Energy Fuels 1999;13:146-53.

Abad A, Adánez J, García-Labiano F, Gayan P. Hot coal-gas desulphurization with calcium based sorbents in a pressurized moving-bed reactor. Energy Fuels 2004; 18:1543-54.

Diego LT, Abad A, García-Labiano F, Adanez J, Gayán P. Simultaneous calcinations and sulfidation of calcium-based sorbents. Ind Eng Chem Res 2004:43:3261-9.

Adánez J, Abad A, García-Labiano F, Diego LF, Gayan P. $\mathrm{H}_{2} \mathrm{~S}$ retention with Cabased sorbents in a pressurized fixed-bed reactor: application to moving-bed design. Fuel 2005;84:533-42.

Mêndez-Vigo I, Elcogas. Puertollano IGCC update. In: Proceedings of gasification technologies international conference. San Francisco, USA <www.coal-ucg.com/publications2.html>; October 2002.

Yiqun Zhang, Zhongbin Xiao, Jianxin Ma. Hydrolysis of carbonyl sulphide over rare earth oxysulfides. Appl Catal B: Environ 2004;48:57-63.

Heesink ABM, Van Swaaij WPM. The sulphidation of calcined limestone with hydrogen sulphide and carbonyl sulphide. Chem Eng Sci 1995:50:2983-96.

Ishida $\mathrm{Y}$, Taki $\mathrm{U}$, Oyama $\mathrm{H}$, Kitagawa $\mathrm{K}$, Matsumoto $\mathrm{K}$. Discriminative determination of hydrogen gas formed from tandem $\mathrm{CO}_{2}$ reforming and shift reaction by isotope labelling followed by cryogenic gas chromatography. Fuel 2006;85:2041-5.

No-Kuk Park, Jong Bae Lee, Tae Jin Lee, Si Ok Ryu, Chih Hung Chang. The preparation of a high surface area metal oxide prepared by a matrix-assisted method hot gas desulphurization. Fuel 2005;84:2165-71. 